\title{
PRZEGLĄD ORZECZNICTWA SĄDU NAJWYŻSZEGO
}

\author{
TOMASZ PAEDYNA
}

Uniwersytet Kardynała Stefana Wyszyńskiego

\section{PRZEDAWNIENIE ROSZCZEŃ PO NOWELIZACJI KODEKSU CYWILNEGO Z 28 LIPCA 1990 ROKU}

Ustawą z dnia 28 lipca 1990 r. o zmianie ustawy - Kodeks cywilny $^{1}$ dokonano gruntownej przebudowy kodeksu cywilnego. Nowelizacją objęto, między innymi, przepisy tytułu VI księgi pierwszej kodeksu regulujące przedawnienie roszczeń ${ }^{2}$. Ustawodawca powrócił do formuły obowiązującej w prawie cywilnym przed wejściem w życie kodeksu cywilnego: sąd nie uwzględnia już przedawnienia $\mathrm{z}$ urzędu, a jedynie na zarzut pozwanego ${ }^{3}$. Zgodnie bowiem $\mathrm{z}$ treścią art. $117 \S 2$ k.c., po uplywie terminu przedawnienia ten, przeciwko komu przysługuje roszczenie, może uchylić się od jego zaspokojenia, chyba że zrzeka się korzystania $\mathrm{z}$ zarzutu przedawnienia. W konsekwencji skreślono $\S 3$ tego artykułu nakazujący uwzględnianie upływu przedawnienia $z$ urzędu i dający sądowi (państwowej

\footnotetext{
${ }^{1}$ Dz.U. Nr 55, poz. 321. Ustawa ta weszła w życie z dniem 1 października $1990 \mathrm{r}$.

${ }^{2}$ Szczególowo nowelizację w tym zakresie omawia A. BRzozowsKI, Nowa regulacja przedawnienia w prawie cywilnym, «PiP» 47.3 (1992), s. 21 i n.

${ }^{3}$ Por. uzasadnienie wyroku z dnia 15 lipca 1999 r., II UKN 44/99, «OSNP» 2000 nr 21, poz. 798. Por. też A. BRZozowsKı, op. cit., s. 24-26.
} 
komisji arbitrażowej lub innemu organowi powołanemu do rozpoznawania spraw danego rodzaju) możliwość „przywrócenia” termi$\mathrm{nu}^{4}$. Dokonano też ujednolicenia skutków upływu terminu przedawnienia. Roszczenie przedawnione nie wygasa, a jedynie ulega pewnemu osłabieniu na skutek przyznania dłużnikowi paraliżującego je zarzutus. „Roszczenia w stosunkach między jednostkami gospodarki uspołecznionej, które podlegają państwowemu arbitrażowi gospodarczemu", przedawniające się z upływem jednego roku ${ }^{6}$, zastąpiono pojęciem „roszczeń związanych z prowadzeniem działalności gospodarczej". Termin przedawnienia tych roszczeń wynosi trzy lata. Skreślono także art. 123 § 2 i 125 § 2 k.c. Oba przepisy wprowadzały szczególne rozwiązania dla jednostek gospodarki uspołecznionej. Zmiany w przepisach art. 121 pkt $4,123 \S 1$ pkt 1 oraz $124 \S 2$ k.c. miały charakter porządkowy i wiązały się $\mathrm{z}$ likwidacją państwowych komisji arbitrażowych?

Przegląd niniejszy obejmuje wybrane orzeczenia Sądu Najwyższego w dziedzinie przedawnienia roszczeń, wydane po dniu 1 października 1990 r. Celem tego opracowania jest bowiem zestawienie orzecznictwa opartego na nowych rozwiązaniach legislacyjnych. Do zagadnień będących przedmiotem analizy należą: zarzut przedawnienia, odmowa uwzględnienia zarzutu przedawnienia $z$ uwagi na sprzeczność z zasadami współżycia społecznego, stosowanie art. 118 k.c., w tym przede wszystkim przedawnienie roszczeń związanych $\mathrm{z}$ prowadzeniem działalności gospodarczej oraz normy intertemporalne.

${ }^{4}$ Por. uzasadnienie wyroku z dnia 2 lutego 2000 r., II CKN 468/99, niepubl.

${ }^{5}$ Przed nowelizacją istnial dualizm skutków przedawnienia: w stosunkach między jednostkami gospodarki uspołecznionej, które podlegały państwowemu arbitrażowi gospodarczemu, roszczenie przedawnione wygasało; w innych stosunkach nie można było roszczenia przedawnionego dochodzić.

${ }^{6}$ Por. art. 117 § 2 k.c. w pierwotnym brzmieniu.

${ }^{7}$ We wszystkich tych przepisach skreślono jedynie słowa ,państwową komisją arbitrażową”. Państwowy Aurbitraż Gospodarczy został zniesiony ustawą z dnia 24 maja 1989 r. o rozpoznawaniu przez sądy spraw gospodarczych (Dz.U. Nr 33, poz. 175). 


\section{ZARZUT PRZEDAWNIENIA}

Zarzut przedawnienia jest prawem podmiotowym dłużnika. Zarzut, w sensie materialnoprawnym, to uprawnienie polegające na odmowie spełnienia roszczenia ${ }^{8}$. Terminem tym posługuje się także prawo cywilne procesowe, gdzie przez zarzut rozumie się czynność procesową zmierzającą do obrony praw $\mathrm{w}$ procesie' ${ }^{9}$. Zarzut przedawnienia to uprawnienie materialnoprawne, choć aktualizuje się ono dopiero w procesie. Być może z uwagi na tę cechę Sąd Najwyższy, w uzasadnieniu uchwały z dnia 10 maja $2000 \mathrm{r}^{10}$, wyraził pogląd, że zarzut przedawnienia „ma przede wszystkim wymiar procesowy".

Mimo iż nie wynika to wprost $\mathrm{z}$ treści art. 117 k.c., to nie ulega wątpliwości, że sąd nie uwzględnia przedawnienia $z$ urzędu ${ }^{11}$. Ten, przeciwko komu przysługuje roszczenie, może uchylić się od jego zaspokojenia, ale nie musi. Sąd nie może w to uprawnienie ingerować. Taka jest bowiem natura zarzutu, jako prawa podmiotowego. Zresztą, zasada ta w orzecznictwie Sądu Najwyższego nie była kontestowana ${ }^{12}$, a wątpliwości co do wykładni art. $117 \S 2$ k.c. dotyczyły jedynie pewnych kwestii szczególnych. W uzasadnieniu wyroku z dnia 6 lutego 2002 r. $^{13}$ czytamy: ,art. 117 \& 2 k.c. mówi tylko

${ }^{8}$ Z. RADWAŃsKI, Prawo cywilne - część ogólna, Warszawa 2002, s. 92.

9 J. Jod owski, Z. Resich, J. LAPIERRE, T. Misiuk-JodłowsKA, Postepowanie cywilne, Warszawa 1997, s. 277; por. też W. SIEDLECKI, Z. ŚwIEBODA, Posteppowanie cywilne. Zarys wykładu, Warszawa 1998, s. 198-201; W. BRONIEWICZ, Postępowanie cywilne w zarysie, Warszawa 1998, s. 190-192.

${ }^{10}$ III ZP 13/00, «OSNP» $2000 \mathrm{nr} 23$, poz. $846 \mathrm{i}$ «OSP» $2001 \mathrm{nr} 6$, poz. 96.

${ }^{11}$ Uchylony art. 117 § 3 k.c. przesądzal tę kwestię wprost stanowiąc, że „sąd ... uwzględnia uplyw przedawnienia z urzędu".

${ }^{12}$ Choć Sąd Najwyższy w swych orzeczeniach odwoluje się do niej. Por. uzasadnienia wyroków z dnia 7 lipca 1995 r., II PRN 6/95, «OSNP» 1996 nr 4, poz. 61 i z dnia 15 lipca 1999 r., II UKN 44/99, «OSNP» $2000 \mathrm{nr} 21$, poz. 798 oraz uzasadnienie uchwały z dnia 10 maja 2000 r., III ZP 13/00, «OSNP» $2000 \mathrm{nr} 23$, poz. $846 \mathrm{i}$ «OSP» $2001 \mathrm{nr} 6$, poz. 96.

${ }^{13} \mathrm{~V}$ CKN 883/00, niepubl. 
o skutku przedawnienia (możliwości uchylenia się zobowiązanego od zaspokojenia roszczenia), a nie o jego przesłankach i terminach. Zastosowanie tego przepisu następuje w konsekwencji ustalenia (w oparciu o prawidłowo określoną podstawę faktyczną i prawną), że przedawnienie nastąpiło". W uzasadnieniu wyroku $\mathrm{z}$ dnia 2 sierpnia 2000 r. ${ }^{14}$ Sąd Najwyższy przyjął, że w sytuacji, gdy zarzut przedawnienia podniesie jeden tylko $z$ pozwanych, to nie odnosi to skutku w stosunku do drugiego pozwanego. Sąd nie może na tej podstawie oddalić powództwa w stosunku do obu pozwanych ${ }^{15}$.

Wykładnia art. 117 k.c. nie nastręcza szczególnych trudności. Po zmianie stanu prawnego ustawą z dnia 28 lipca 1990 r. ${ }^{16}$ wątpliwości, co do obowiązywania zasady nieuwzględniania przedawnienia $\mathrm{z}$ urzędu, zrodziły się na tle pewnych regulacji znajdujących się poza kodeksem cywilnym. W niektórych bowiem przepisach pozakodeksowych, normujących przedawnienie, ustawodawca posłużył się formułą językową odbiegającą od przyjętej w art. $117 \S 2$ k.c. We wszystkich tych przypadkach Sąd Najwyższy przyjmował konsekwentnie, że sąd nie uwzględnia przedawnienia $z$ urzędu ${ }^{17}$.

\section{Przedawnienie roszczeń wekslowych}

Do przepisów takich należy art. 76 prawa wekslowego ${ }^{18}$, który mówi o wygaśnięciu zobowiązania wekslowego na skutek przedaw-

${ }^{14}$ I PKN 746/99, «OSNP» 2002 nr 4, poz. 85.

${ }^{15}$ Podkreślenia wymaga, że zasada ta została sformułowana na tle konkretnego stanu faktycznego (pozwanymi w sprawie o zapłatę odszkodowania i renty uzupelniającej byli solidarnie Skarb Państwa i szpital) i nie musi mieć waloru ogólnego.

${ }^{16}$ Przywolaną w przyp. 1.

${ }^{17}$ Stanowisko takie zasługuje na pełną aprobatę. Kodeks cywilny stanowi trzon prawa cywilnego, a przyjęte w nim rozwiązania konstrukcyjne winny dotyczyć całego systemu. Przyjęcie odmiennych rozwiązań w przepisach pozakodeksowych domaga się szczególnego uzasadnienia i musi wyraźnie wynikać z treści przepisu. Por. nieobowiązujący już art. 292 § 2 kodeksu pracy, o którym mowa w kolejnych uwagach.

${ }^{18}$ Ustawa z dnia 28 kwietnia 1936 r. (Dz.U. Nr 37, poz. 282). 
nienia. W ocenie Sądu Najwyższego z faktu, że prawo wekslowe posługuje się inną terminologią niż kodeks cywilny, nie można wyprowadzić odmiennych wniosków co do skutków przedawnienia roszczeń wekslowych, niż wynikające $z$ art. 117 k.c. Podobnie jak w kodeksie cywilnym, upływu terminu przedawnienia roszczeń wekslowych nie uwzględnia się z urzędu' ${ }^{19}$.

\section{Przedawnienie roszczeń ze stosunku pracy}

Wątpliwości co do obowiązywania zasady uwzględniania upływu przedawnienia na zarzut zrodziły się także na płaszczyźnie prawa pracy, a to $z$ uwagi na treść art. 292 kodeksu pracy, zmienionego ustawą z dnia 2 lutego 1996 r. o zmianie ustawy - Kodeks pracy oraz o zmianie niektórych ustaw ${ }^{20}$. Art. 292 k.p. jest odpowiednikiem art. 117 k.c. Nowelizacja art. 292 k.p. ograniczyła się do skreślenia § 2 tego przepisu, będącego kalką art. 117 § 3 k.c. Do dnia wejścia w życie ustawy zmieniającej k.p., tj. do dnia 2 czerwca 1996 r., w sprawach $\mathrm{z}$ zakresu prawa pracy sąd uwzględniał przedawnienie $\mathrm{z}$ urzędu. Mógł jednak nie uwzględnić upływu przedawnienia, jeżeli opóźnienie w dochodzeniu roszczenia było usprawiedliwione wyjątkowymi okolicznościami i nie było nadmierne.

Przeprowadzona zmiana miała na celu dostosowanie konstrukcji przedawnienia uregulowanego kodeksem pracy do art. 117 k.c. Nowelizacja nie rozwiała jednak wszystkich wątpliwości. W art. 292 k.p. ustawodawca posługuje się zwrotem „roszczenia przedawnionego nie można dochodzić", odmiennie niż w art. 117 § 2 k.c., gdzie dłużnik „może uchylić się od jego zaspokojenia”. W związku z tym powstaje wątpliwość, czy mimo skreślenia art.

${ }^{19}$ Uzasadnienie wyroku z dnia 7 stycznia 1998 r., II CKN 565/97, «OSNC» 1998 nr 7-8, poz. 121, «OSP» $1998 \mathrm{nr} 11$, poz. 193 oraz «PPH» 7.11 (1998), s. 46. Por. aprobujące glosy do tego orzeczenia A. SzPUNARA, «OSP» $1998 \mathrm{nr} 11$, s. 550-552 i M. LITWIŃSKIEJ, «PPH» 7.12 (1998), s. 43-46.

${ }^{20}$ Dz.U. Nr 24, poz. 110, ze zm. 
$292 \S 2$ k.p., w sprawach z zakresu prawa pracy roszczenie przedawnione nie wygasa. Okoliczność tę sąd musiałby uwzględniać z urzędu. Zagadnienie to rozstrzygnęła uchwała Sądu Najwyższego z dnia 10 maja 2000 r. $^{21}$, w której przyjęto, że „w sprawach o roszczenia ze stosunku pracy sąd nie uwzględnia $\mathrm{z}$ urzędu upływu terminu przedawnienia"22. W uzasadnieniu zwrócono uwagę na to, że zamierzenie ustawodawcy ujednolicenia systemu nie zostało jednoznacznie odzwierciedlone w treści art. 292 k.p. Przyjęcie jednak odmiennego poglądu, od wyrażonego w treści uchwały, byłoby sprzeczne $\mathrm{z}$ wyraźną wolą ustawodawcy, a nadto zakładałoby jego nieracjonalne działanie. „Oznaczałoby bowiem, że w istocie nie wprowadzono żadnej zmiany treści przepisu, mimo iż ustawodawca wyraźnie chciał to uczynić oraz dokonał zmiany przepisów i to tak jednoznacznej, jak skreślenie jednej jego części”. W uzasadnieniu tym zauważa się też, że ujednolicenie systemu przedawnienia roszczeń jest racjonalne i było powszechnie postulowane w doktrynie. W ocenie Sądu Najwyższego „przy wykładni art. 292 k.p. należy dać pierwszeństwo woli ustawodawcy, działającego racjonalnie i zgodnie $\mathrm{z}$ postulowanymi kierunkami zmian, a nie niezbyt precyzyjnej treści przepisu".

3. Przedawnienie roszczeń odszkodowawczych za niesłuszne skazanie, aresztowanie lub zatrzymanie

Wątpliwości interpretacyjnych dostarczyły także przepisy kodeksu postępowania karnego z $1969 \mathrm{r}^{23}$ regulujące odszkodowanie za niesłuszne skazanie, tymczasowe aresztowanie i zatrzymanie, a to za sprawą art. 489 k.p.k., posługującego się zwrotem „nie można żądać

${ }^{21}$ III ZP 13/00, «OSNP» $2000 \mathrm{nr} 23$, poz. $846 \mathrm{i}$ «OSP» $2001 \mathrm{nr} 6$, poz. 96.

22 Takie samo stanowisko Sąd Najwyższy zajął w uzasadnieniu uchwały z dnia 6 marca 1998 r., III ZP 50/97, «OSNAPiUS» 1998 nr 18, poz. 534.

${ }^{23}$ Nieobowiązująca już ustawa z dnia 19 kwietnia 1969 r. (Dz.U. Nr 13, poz. 96, ze $\mathrm{zm})$. 
odszkodowania i zadośćuczynienia"24. Początkowo dość powszechnie przyjmowano w judykaturze, że terminy określone w art. 489 k.p.k. są terminami prekluzyjnymi ${ }^{25}$. Jednak w nowszym orzecznictwie zwyciężył pogląd głoszący, że są to cywilnoprawne terminy przedawnienia, a sąd nie uwzględnia ich uplywu $z$ urzędu ${ }^{26}$. Podmiotem uprawnionym do podniesienia zarzutu przedawnienia jest $w$ tym postępowaniu prokurator ${ }^{27}$. Nowy kodeks postępowania karnego ${ }^{28}$ ucina dyskusję na temat charakteru tych terminów. $Z$ art. 555 k.p.k., będącego odpowiednikiem art. 489 dawnego k.p.k., wynika bowiem wprost, że roszczenia, o których mowa w tym przepisie, „przedawniają się”.

W uzasadnieniu postanowienia $z$ dnia 3 marca 1994 r. ${ }^{29}$ Sąd Najwyższy przyjąl, że termin określony w art. 8 ust. 2 ustawy z dnia 23

${ }^{24}$ Por. A. SzPunAR, O terminie z art. 489 k.p.k. i skutkach jego uptywu, «Nowe Prawo» 30.9-10 (1982), s. 51 i n.; S. WALtoś, Proces karny. Zarys systemu ${ }^{3}$, Warszawa 1980, s. 499-500.

${ }^{25}$ Tak m.in. postanowienia Sądu Najwyższego z dnia 7 listopada 1970 r., II KZ 127/70, «OSNPG» 1971 nr 5, poz. 94; z dnia 19 lutego 1977 r., V KZ 115/76, «OSNPG» $1977 \mathrm{nr} 11$, poz. 120; z dnia 8 grudnia 1979 r., II KZ 216/79, «OSNKW» $1980 \mathrm{nr}$ 2, poz. 23; z dnia 4 lutego 1983 r., IV KZ 2/83, «OSNPG» $1983 \mathrm{nr} 5$, poz. 56 i z dnia 12 stycznia 1990 r., WZ 67/89, «OSNKW» $1990 \mathrm{nr}$ 7-12, poz. 33. Odmienne zapatrywanie wyraził Sąd Najwyższy w postanowieniu z dnia 14 maja 1982 r., II KZ 38/82, «OSNKW» 1982 nr 9, poz. 63, gdzie przyjęto, iż termin określony w art. 489 k.p.k. jest terminem przedawnienia.

${ }^{26}$ Uchwała składu 7 sędziów z dnia 19 lutego 1997 r., I KZP 38/96, «OSNKW» $1997 \mathrm{nr} 3-4$, poz. 18 oraz jej uzasadnienie. Takie samo stanowisko zajął Sąd Najwyższy w uzasadnieniu postanowienia z dnia 5 września 1995 r., WZ 141/95, «OSNKW» 1996 nr 5-6, poz. 30 oraz w uzasadnieniu wyroku z dnia 18 października 2002 r., V KK 259/02, niepubl.

${ }^{27}$ Uzasadnienie uchwały składu 7 sędziów z dnia 19 lutego 1997 r., I KZP 38/96, «OSNKW» $1997 \mathrm{nr} 3-4$, poz. 18. Tak też, choć mniej zdecydowanie, w uzasadnieniu uchwały składu 7 sędziów z dnia 30 września 1993 r., I KZP 7/93, «OSNKW» $1993 \mathrm{nr} 11-12$, poz. 66 oraz w uzasadnieniu postanowienia $\mathrm{z}$ dnia 5 września 1995 r., WZ 141/95, «OSNKW» 1996 nr 5-6, poz. 30, gdzie przyjęto, że „wiele przemawia za przyjęciem stanowiska, w świetle którego podmiotem uprawnionym do podniesienia zarzutu przedawnienia jest w tym postępowaniu prokurator".

${ }^{28}$ Ustawa z dnia 6 czerwca 1997 r. (Dz.U. Nr 89, poz. 555).

${ }^{29}$ I KZP 2/94, «Jurysta» 1994 nr 7-8, s. 43. 
lutego 1991 r. o uznaniu za nieważne orzeczeń wydanych wobec osób represjonowanych za działalność na rzecz niepodległego bytu państwa polskiego ${ }^{30}$ jest cywilnoprawnym terminem przedawnienia, a nie terminem prekluzyjnym, zatem zgłoszenie żądania odszkodowania i zadośćuczynienia po jego upływie prowadzi do oddalenia tego żądania tylko w razie podniesienia zarzutu przedawnienia.

\section{Podniesienie zarzutu przedawnienia}

Po przywróceniu zasady, zgodnie z którą sąd uwzględnia przedawnienie jedynie na zarzut uprawnionego, odży problem, w którym ze stadiów postępowania zarzut taki może być podniesiony. Problem ten, niezauważony przez doktrynę ${ }^{31}$, był przedmiotem analizy Sądu Najwyższego. Nie ulega wątpliwości, że zarzut przedawnienia może być podniesiony aż do zamknięcia rozprawy w I instancji, nie może zaś być podstawą skargi kasacyjnej ani być podnoszony $\mathrm{w}$ toku postępowania kasacyjnego ${ }^{32}$. Zgłaszanie bowiem $\mathrm{w}$ postępowaniu kasacyjnym nowych okoliczności faktycznych jest niedopuszczalne ${ }^{33}$. Wątpliwości dotyczą w zasadzie możliwości podnoszenia zarzutu przedawnienia w postępowaniu apelacyjnym. W najnowszym orzecznictwie Sądu Najwyższego przyjmuje się, że zarzut przedawnienia może być skutecznie zgłoszony do chwili zamknięcia rozprawy przed sądem drugiej instancji ${ }^{34}$.

${ }^{30}$ Dz.U. Nr 34, poz. 149 , ze zm.

${ }^{31} \mathrm{Na}$ co zwraca uwagę B. KoRDASIEWICZ, op. cit., s. 566.

${ }^{32}$ Por. B. KordasiewICZ, op. cit., s. 566.

${ }^{33}$ Tak w uzasadnieniu wyroku z dnia 7 stycznia 1998 r., II CKN 565/97, «OSNC» $1998 \mathrm{nr} 7-8$, poz. 121, «OSP» 1998 nr 11, poz. 193 oraz «PPH» 7.11 (1998), s. 46. Tak też, jak się wydaje, w uzasadnieniu wyroku z dnia 2 lutego 2000 r., II CKN 468/99, niepubl.

${ }^{34}$ Tak w uzasadnieniu wyroku z dnia 4 marca 2002 r., V CKN 829/00, «Biuletyn SN» $2003 \mathrm{nr} 1$, poz. 8 oraz w uzasadnieniu wyroku z dnia 19 lipca 2001 r., II UKN 475/00, «OSNP» $2003 \mathrm{nr} 8$, poz. 210. 


\section{NADUŻYCIE PRAWA W DZIEDZINIE PRZEDAWNIENIA}

1. Dopuszczalność stosowania klauzuli nadużycia prawa do zarzutu przedawnienia

Na tle stanu prawnego obowiązującego do dnia 1 października 1990 r. przyjmowano dość powszechnie, zarówno w orzecznictwie, jak i w doktrynie, że niedopuszczalne jest stosowanie konstrukcji nadużycia prawa podmiotowego $w$ stosunkach dotyczących przedawnienia $a^{35}$. Stanowisko takie znajdowało uzasadnienie $w$ treści art. 117 § 3 k.c., w którym zamieszczono klauzulę umożliwiającą sądowi nieuwzględnienie upływu przedawnienia, gdy termin przedawnienia nie przekraczał trzech lat, a opóźnienie nie było nadmierne. Ustawodawca zaszczepił w ten sposób, w obszarze instytucji przedawnienia klauzulę nadużycia prawa, w ograniczonej jednak postaci ${ }^{36}$. Niedopuszczalność stosowania instrumentu $z$ art. 5 k.c. do przedawnienia roszczeń uzasadniano dwojako. Podnoszono, po pierwsze, iż przepis art. 117 § 3 k.c. stanowi lex specialis w stosunku do regulacji z art. 5 k.c. ${ }^{37}$ Po drugie, twierdzono, nie bez racji, że z uwagi na uwzględnianie przez sąd przedawnienia $\mathrm{z}$ urzę-

${ }^{35}$ A. Wolter, Prawo cywilne. Zarys części ogólnej, Warszawa 1967, s. 299; A. SzPUNAR, Nadużycie prawa $w$ dziedzinie przedawnienia, «RPEiS» 31.4 (1969), s. 43 i n.; J. IGNATOWICZ, [w:] System prawa cywilnego'2, I, Wrocław 1985, s. 810-813; S. GRZYBOWSKI, System prawa cywilnego, I, Wrocław 1974, s. 640; W. BRYL, Kodeks cywilny. Komentarz, I, Warszawa 1972, s. 269. Tak też Sąd Najwyższy w orzeczeniach z dnia 4 marca 1966 r., II PR 34/66, «OSPiKA» 11.9 (1966), poz. 210 oraz z dnia 4 października 1967 r., II PR 340/67, «OSPiKA»13.7-8 (1968), poz. 162, to ostatnie z glosą aprobującą A. SzPunARA, Nadużycie prawa, cit., s. 346 i n.; por. także glosę W. SANETRY, «PiP» 23.12 (1968), s. 1079 i n., polemizującą z ostatnim z wymienionych orzeczeń. Odmienne stanowisko, dopuszczające możliwość stosowania klauzuli z art. 5 k.c. do przedawnienia zająl, poza W. Sanetrą, S. DALKA, Skutki prawne przedawnienia zobowiązań, Warszawa 1972, s. 73-74.

${ }^{36} \mathrm{~J}$. IGNATOWICZ, op. cit, s. 811.

${ }^{37}$ A. Wolter, Rola zasad wspótzycia spolecznego w nowych kodeksach, «NP» 20.11 (1964), s. 1040; A. SZPUNAR, Nadużycie prawa, cit., s. 43; Z. KLAFKOWSKI, Przedawnienie w prawie cywilnym, Warszawa 1970, s. 226-227; W. Bryl, op. cit., s. 269. 
du nie ma miejsca na nadużycie prawa ${ }^{38}$. W związku z upływem terminu przedawnienia dłużnikowi nie służyło żadne prawo podmiotowe, które by miał wykonywać, nie mógł więc go nadużyć.

Po uchyleniu art. 117 § 3 k.c. powrócono do sytuacji, z jaką mieliśmy do czynienia przed wejściem w życie kodeksu cywilne$\mathrm{go}^{39}$. W orzecznictwie Sądu Najwyższego przyjmowano wówczas, że sąd może nie uwzględnić zarzutu przedawnienia, gdy pozostaje on w sprzeczności z zasadami współżycia społecznego ${ }^{40}$. Takie samo stanowisko prezentuje Sąd Najwyższy w najnowszym orzecznictwie $^{41}$, jednak obecnie zaleca przy tym daleko idącą ostrożnośćc ${ }^{42}$. Podkreśla się, że sąd może uznać zgłoszony zarzut przedawnienia za sprzeczny z zasadami współżycia społecznego „w wyjątkowych okolicznościach”, „w szczególnie drastycznych okoliczno-

${ }^{38}$ J. IGNatowicz, op. cit., s. 811-812; A. Wolter, Prawo cywilne, cit., s. 299; Por. także uwagi B. KORDASIEWICZA, op. cit., s. 568-569 i T. JUSTYŃSKIEGO, Nadużycie prawa w polskim prawie cywilnym, Kraków 2000, s. 174.

${ }^{39}$ Por. art. 3 oraz 105 i nast. ustawy z dnia 18 lipca 1950 r. Przepisy ogólne prawa cywilnego (Dz.U. nr 34, poz. 311).

${ }^{40}$ Tytułem przykładu orzeczenie $\mathrm{z}$ dnia 25 października - 7 listopada 1957 r., 2 CR 332/56, «OSN» $1958 \mathrm{nr} 4$, poz. 112; uchwała z dnia 27 czerwca 1963 r., II PO 12/63, «OSPiKA» 9.5 (1964), poz. 98, z aprobującą glosą B. DoBRZYŃSKIEGO, «OSPiKA» 9.5 (1964), s. 220-223.

${ }^{41}$ Przykładowo uchwała $z$ dnia 10 marca 1993 r., III CZP 8/93, «OSP» 1993, Nr 12, poz. 244 oraz «OSNC» $1993 \mathrm{nr} 9$, poz. 153; uzasadnienia postanowień z dnia 3 marca 1994 r., I KZP 2/94, «Jurysta» 1994 nr 7-8, s. 43; z dnia 5 września 1995 r., WZ 141/95, «OSNKW» 1996 nr 5-6, poz. 30; z dnia 5 października 1996 r., KPZ 141/95, "MoP» 4.12 (1996), s. 463; uchwała z dnia 11 października 1996 r., III CZP 76/96, «OSNC» 1997, Nr 2, poz. 16; uzasadnienie wyroku z dnia 29 października 1998 r., II UKN 282/98, «OSNP» $1999 \mathrm{nr}$ 23, poz. 758; uzasadnienie uchwały z dnia 10 maja 2000 r., III ZP 13/00, "OSNP» $2000 \mathrm{nr} 23$, poz. 846 oraz «OSP» $2001 \mathrm{nr} 6$, poz. 96; uzasadnienia wyroków z dnia 17 października 2000 r., V KKN 321/98, niepubl.; z dnia 27 czerwca 2001 r., II CKN 604/00, «OSNC» 2002 nr 3, poz. 32 i z dnia 8 listopada 2002 r., III CKN 1115/00, niepubl.

${ }^{42}$ Tytułem przykładu uzasadnienia wyroków $z$ dnia 2 lutego 2000 r., II CKN 468/99, niepubl.; z dnia 29 maja 2001 r., I CKN 1151/00, niepubl.; z dnia 19 lipca 2001 r., II UKN 475/00, «OSNP» $2003 \mathrm{nr} 8$, poz. 210 i z dnia 12 grudnia 2002 r., V CKN 1548/00, niepubl. 
ściach”43, „w szczególnych, wyjątkowych sytuacjach”"4, „w wyjątkowo rażących i rzadkich okolicznościach”,4s, „zupełnie wyjątkowo”"46. Bezczynność wierzyciela w dochodzeniu roszczenia musi być usprawiedliwiona wyjątkowymi okolicznościami ${ }^{47}$. W orzecznictwie Sądu Najwyższego dostrzeżono także ryzyko „uzupełniania ustawodawcy" w drodze wykładni dokonywanej przez pryzmat art. 5 k.c. ${ }^{48}$

Według Sądu Najwyższego, okolicznością uzasadniającą zastosowanie klauzuli zasad współżycia społecznego w odpowiedzi na zarzut przedawnienia może być fakt, iż roszczenie wynika ze zbrodni stalinowskich $^{49}$, nielojalne zachowanie dłużnika, przejawiające się w „uśpieniu czujności wierzyciela"'s0, niezachowanie przez praco-

${ }^{43}$ Oba przykłady zaczerpnięto $z$ uzasadnienia uchwały z dnia 10 marca 1993 r., III CZP 8/93, «OSP» $1993 \mathrm{nr} 12$, poz. 244 oraz «OSNC» $1993 \mathrm{nr}$ 9, poz. 153. Por. także uzasadnienie wyroku z dnia 11 września 1997 r., II UKN 230/97, «OSNP» $1998 \mathrm{nr} 13$, poz. 406 oraz postanowienia z dnia 5 września 1995 r., WZ 141/95, «OSNKW» $1996 \mathrm{nr} 5-6$, poz. 30.

" Uzasadnienie wyroku z dnia 29 października 1998 r., II UKN 282/98, „OSNP» $1999 \mathrm{nr} 23$, poz. 758.

${ }^{45}$ Uzasadnienie wyroku z dnia 26 stycznia 2000 r., III CKN 566/98, niepubl.

${ }^{40}$ Uzasadnienie wyroku z dnia 7 czerwca 2000 r., III CKN 522/99, niepubl. Por. także uzasadnienie wyroku $z$ dnia 23 sierpnia 2001 r., II CKN 103/99, niepubl., w którym przyjęto, że domniemanie przemawia za tym, że ten, kto korzysta z zarzutu przedawnienia, czyni to zgodnie z zasadami wspólżycia społecznego i dopiero istnienie szczególnych okoliczności może obalić to domniemanie.

${ }^{47}$ Uzasadnienie wyroku z dnia 7 czerwca 2000 r., III CKN 522/99, niepubl.

${ }^{48}$ Uzasadnienie wyroku z dnia 29 października 1998 r., II UKN 282/98, «OSNP» $1999 \mathrm{nr} 23$, poz. 758.

49 Uzasadnienie wyroku z dnia 29 maja 2001 r., I CKN 1151/00, niepubl.

${ }^{50}$ Chodzi o zachowanie polegające na zwodzeniu wierzyciela, gdy dłużnik swoim postępowaniem, np. przez podejmowanie pertraktacji lub innych działań, wywołał przekonanie wierzyciela, że dobrowolnie spełni swoje świadczenie. Tak w uzasadnieniu wyroku z dnia 27 czerwca 2001 r., II CKN 604/00, «OSNC» 2002 $\mathrm{nr} 3$, poz. 32. W uzasadnieniu tym podniesiono także, że dłużnik, w efekcie podniesionego w toku postępowania zarzutu przedawnienia, uzyskałby korzyść majątkową w wyniku swego niewłaściwego postępowania. Por. też uzasadnienia wyroków z dnia 15 lipca 1999 r., II UKN 44/99, «OSNP» 2000, Nr 21, poz. 798 i z dnia 4 października 2001 r., I CKN 458/00, niepubl. 
dawcę bezpiecznych i higienicznych warunków pracy ${ }^{51}$, „niezwykle dolegliwy dla powoda" charakter następstw wypadku przy pracy ${ }^{52}$, niedopełnienie przez publiczny zakład opieki zdrowotnej obowiąz$\mathrm{ku}$ informowania pacjenta o stanie zdrowia ${ }^{53}$, a nawet krótki termin przedawnienia $^{54}$. Do okoliczności natomiast, które nie uzasadniały odmowy uwzględnienia zarzutu przedawnienia ze względu na nadużycie prawa, Sąd Najwyższy zaliczył korzystanie przez powodów, którzy dopuścili się uchybienia terminowi przedawnienia, $z$ fachowej pomocy prawnej przed jego upływem ${ }^{55}$, inwalidztwo III grupy ${ }^{56}$, nieznajomość prawa, powołana przez powoda dla usprawiedliwie-

${ }^{51}$ Uzasadnienia wyroków z dnia 6 marca 1996 r., II PRN 3/96, «OSNP» $1996 \mathrm{nr}$ 18, poz. 264 i z dnia 15 lipca 1999 r., II UKN 44/99, «OSNP» $2000 \mathrm{nr}$ 21, poz. 798.

52 Uzasadnienia wyroków z dnia 17 marca 1998 r., II UKN 556/97, «OSNP» $1999 \mathrm{nr} 5$, poz. 183 oraz z dnia 15 lipca 1999 r., II UKN 44/99, «OSNP» $2000 \mathrm{nr} 21$, poz. 798. Podobnie w uzasadnieniu wyroku z dnia 6 marca 1996 r., II PRN 3/96, «OSNP» $1996 \mathrm{nr}$ 18, poz. 264.

${ }^{53}$ Uzasadnienie wyroku $z$ dnia 8 listopada 2002 r., III CKN 1115/00, niepubl.

${ }^{54}$ Uzasadnienie uchwały składu 7 sędziów z dnia 29 listopada 1996 r., II PZP 3/96, «OSNP» $1997 \mathrm{nr} 14$, poz. 249. Sąd Najwyższy przyjął w przywolanym uzasadnieniu, że „nie można przejść do porządku nad tym, że restrykcyjność ... przepisu może w przypadku szkód powstałych wskutek chorób zawodowych prowadzić do naruszenia zasad wspólżycia społecznego". Podobnie, lecz nieco ostrożniej, w uzasadnieniu wyroku z dnia 29 maja 2001 r., I CKN 1151/00, niepubl., gdzie czytamy: „Nie bez znaczenia jest, że w rozpoznawanym wypadku chodzi o stosunkowo krótki, bo roczny termin przedawnienia”. Dodaje się jednak, „że jest to termin stanowiący element obowiązującego prawa i mimo jednoznacznej oceny zbrodni stalinowskich ustawodawca nie zdecydował się na jego wyłączenie lub przedłużenie w razie dochodzenia roszczeń, których źródłem są te zbrodnie".

${ }^{55}$ Uzasadnienie wyroku z dnia 26 stycznia 2000 r., III CKN 566/98, niepubl.

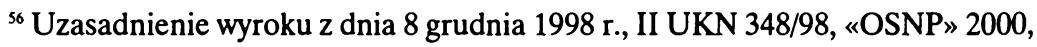
$\mathrm{Nr}$ 2, poz. 77. W uzasadnieniu tym czytamy: „inwalidztwo powoda według III grupy nie było przeszkodą w kontaktowaniu się ze światem zewnętrznym i w skierowaniu żądań odszkodowawczych na odpowiednią drogę i w odpowiednim czasie. Nie bez znaczenia jest także okoliczność, że w wyniku wypadku powód nie utracil całkowicie zdolności do zarobkowania i przez wiele lat był zatrudniony u strony pozwanej, uzyskując dodatkowe źródlo dochodu, pozwalające mu zmniejszyć straty finansowe wynikle $z$ wypadku". 
nia wystąpienia $\mathrm{z}$ pozwem $\mathrm{w}$ cztery lata po przedawnieniu roszczenia $^{57}$, nieznaczne przekroczenie terminu ${ }^{58}$.

Przyjmuje się, że nieuwzględnienie upływu przedawnienia w oparciu o art. 5 k.c. może mieć miejsce także w obrocie profesjonalnym, pomiędzy przedsiębiorcamis ${ }^{\text {}}$. Sąd Najwyższy dopuszcza także możliwość stosowania klauzuli $\mathrm{z}$ art. 5 k.c. do niektórych terminów zawitych. W uchwale z dnia 10 marca 1993 r. ${ }^{60}$ przyjęto, że od chwili wejścia w życie ustawy z dnia 28 lipca 1990 r. o zmianie ustawy - Kodeks cywilny skorzystanie z zarzutu przedawnienia roszczenia majątkowe-

${ }^{57} \mathrm{~W}$ tym samym uzasadnieniu.

${ }^{58}$ Uzasadnienie wyroku z dnia 11 września 1997 r., II UKN 230/97, «OSNP» $1998 \mathrm{nr} 13$, poz. 406. W uzasadnieniu tym Sąd Najwyższy przyjąl, że „zawsze w przypadku wprowadzenia pewnej cezury czasowej istnieje możliwość jej przekroczenia w sposób mniej lub bardziej znaczny. Wprowadzenie jej jednak służy określonemu celowi - w przypadku przedawnienia roszczeń uniemożliwia osobie uprawnionej domagania się od oznaczonej osoby określonego zachowania się (świadczenia) w nieskończonym przedziale czasowym i dla zachowania pewności w obrocie prawnym zamyka możliwość tego żądania w zakreślonych ramach czasowych". W przypadku, będącym przedmiotem rozpoznania w tej sprawie, opóźnienie $\mathrm{z}$ wytoczeniem powództwa wynosilo trzy i pół miesiąca. Podobne stanowisko znajdujemy w wyroku z dnia 7 czerwca 2000 r., III CKN 522/99, niepubl., gdzie uwzględniono zarzut przedawnienia roszczenia o naprawienie szkody wyrządzonej powódce w latach czterdziestych, gdy była więziona ze względów politycznych, z uwagi na dwuletnie opóźnienie w wytoczeniu powództwa, licząc ten termin od czasu, gdy wytoczenie powództwa w tej sprawie stało się możliwe. Odmienne stanowisko zajął Sąd Najwyższy w uzasadnieniu wyroku z dnia 2 lutego 2000 r., II CKN 468/99, niepubl., gdzie nie uwzględniono upływu przedawnienia z powołaniem się na zasady współżycia społecznego w sytuacji, gdy termin przekroczono o szesnaście dni i to jedynie poprzez nieprzedłożenie kontrahentowi dokumentów, które okazały się konieczne, a których tamten wcale się nie domagal.

${ }^{59}$ Takie stanowisko zajął Sąd Najwyższy w uzasadnieniu wyroku z dnia 27 czerwca 2001 r., II CKN 604/00, «OSNC» $2002 \mathrm{nr} 3$, poz. 32. W uzasadnieniu tym Sąd Najwyższy podkreśla, że art. 5 k.c. jest tak ujęty, że może być stosowany do wszystkich podmiotów. Podobnie w uzasadnieniach wyroków $\mathrm{z}$ dnia 4 października 2001 r., I CKN 458/00 i z dnia 3 października 2000 r., I CKN 308/00, «Biuletyn SN» $2001 \mathrm{nr} 1$, poz. 9.

${ }^{60}$ III CZP 8/93, «OSP» $1993 \mathrm{nr}$ 12, poz. 244 oraz «OSNC» $1993 \mathrm{nr}$ 9, poz. 153. 
go, dochodzonego z tytułu rękojmi, może być w wyjątkowych okolicznościach uznane za sprzeczne z zasadami współżycia społecznego ${ }^{61}$.

\section{Badanie przez sąd zgodności zarzutu przedawnienia} $\mathrm{z}$ zasadami współżycia społecznego

Powszechnie przyjmuje się, że treść art. 5 k.c. powinna być brana przez sąd pod rozwagę z urzędu w każdej sprawie ${ }^{62}$. Okoliczność tę akcentuje się silnie w orzeczeniach Sądu Najwyższego zapadłych na tle art. 555 k.p.k. (art. 489 k.p.k. z 1969 r.), co jest uzasadniane przede wszystkim regułami procedury karnej, stosowanej w sprawach o odszkodowanie za niesłuszne skazanie, tymczasowe aresztowanie i zatrzymanie, a nie natura klauzuli $z$ art. 5 k.c. ${ }^{63}$ Nadto prokurator winien wskazać, iż podniesienie przez niego zarzutu przedawnienia jest celowe ze względu na zasady współżycia spolecznego ${ }^{64}$. Podobnie konieczność badania z urzędu, czy zarzut przedawnienia nie pozostaje $w$ sprzeczności $z$ zasadami współżycia społecznego, podkreśla się $\mathrm{w}$ sprawach $\mathrm{z}$ zakresu prawa pracy, kładąc jednak akcent na funkcję zasad współżycia społecznego ${ }^{65}$.

${ }^{61}$ Orzeczenie to, nawiązujące do treści art. $568 \S 1$ k.c., oparte jest na blędnym założeniu, że mamy tu do czynienia z przedawnieniem, a w konsekwencji, że dłużnik może podnieść zarzut przedawnienia. Roszczenia, o których mowa w tej uchwale, nie ulegają przedawnieniu, lecz prekluzji. O zarzucie przedawnienia nie ma zatem mowy. Niemniej jednak, stanowisko to utrwaliło się w orzecznictwie Sądu Najwyższego. Teza przywołanej uchwały została niemal dosłownie powtórzona w uzasadnieniu wyroku z 12 kwietnia 2001 r., II CKN 588/99, niepubl.

${ }^{62}$ T. JUSTYŃSKI, op. cit., s. 126; W. Bryl, op. cit., s. 59; S. DMOWSKI, Komentarz do kodeksu cywilnego. Księga pierwsza - część ogólna ${ }^{2}$, [Miejsce i rok wtdania], s. 29.

${ }^{63}$ Por. uzasadnienie postanowienia $z$ dnia 15 lutego 2001 r., III KKN 595/00, niepubl. oraz wyroku z dnia 18 października 2002 r., V KK 259/02, niepubl.

${ }^{64}$ Tak w uzasadnieniu postanowienia $z$ dnia 7 listopada 2001 r., III KKN 137/01, niepubl.

${ }^{65} \mathrm{~W}$ uzasadnieniu wyroku z dnia 6 marca 1996 r., II PRN 3/96, "OSNP» 1996, $\mathrm{Nr} 18$, poz. 264, Sąd Najwyższy przyjąl, że zasady wspólżycia społecznego winny 


\section{ROSZCZENIA ZWIAZZANE Z PROWADZENIEM DZIALALNOŚCI GOSPODARCZEJ}

\section{Pojęcie roszczeń związanych z prowadzeniem działalności gospodarczej}

Z uwagi na zmianę treści art. 118 k.c. zachodzi konieczność zdefiniowania pojęcia „roszczeń związanych z prowadzeniem działalności gospodarczej”. W orzecznictwie Sądu Najwyższego przyjmuje się, że „hipotezą art. 118 k.c. objęty jest podmiot, który profesjonalnie i zawodowo trudni się działalnością gospodarczą ${ }^{66}$. Nie chodzi jednak w tym przepisie o wszelkie roszczenia podmiotu prowadzącego działalność gospodarczą, a jedynie o roszczenia pozostające w funkcjonalnym związku z zakresem prowadzonej działalności gospodarczej ${ }^{67}$.

być traktowane jako immanentny czynnik wszelkiego zachowania. Treść art. 5 k.c. nie daje podstaw do czynienia jakichkolwiek wyłączeń w zakresie stosowania normy w nim zawartej, która powinna być wzięta pod uwagę przy rozstrzygnięciu każdej sprawy. W uzasadnieniu tym przyjęto, że nierozważenie przez sąd zarzutu przedawnienia w świetle zasad wspólżycia spolecznego stanowi naruszenie prawa.

${ }^{65} \mathrm{~W}$ uzasadnieniu wyroku z dnia 6 marca 1996 r., II PRN 3/96, «OSNP» 1996, $\mathrm{Nr} 18$, poz. 264, Sąd Najwyższy przyjąl, że zasady wspólżycia spolecznego winny być traktowane jako immanentny czynnik wszelkiego zachowania. Treść art. 5 k.c. nie daje podstaw do czynienia jakichkolwiek wyłączeń w zakresie stosowania normy w nim zawartej, która powinna być wzięta pod uwagę przy rozstrzygnięciu każdej sprawy. W uzasadnieniu tym przyjęto, że nierozważenie przez sąd zarzutu przedawnienia w świetle zasad współżycia spolecznego stanowi naruszenie prawa.

${ }^{6}$ Uzasadnienie uchwaly z dnia 26 kwietnia 2002 r., III CZP 21/02, «OSNC» $2002 \mathrm{nr} 12$, poz. 149 oraz «PPH» 12.8 (2003), s. 54.

${ }^{67}$ Por. uzasadnienie uchwały składu 7 sędziów z dnia 11 stycznia 2002 r., III CZP 63/01, «OSNC» $2002 \mathrm{nr} 9$, poz. $106 \mathrm{i}$ «OSP» $2002 \mathrm{nr} 10$, poz. 125 oraz wyroku z dnia 26 listopada 1998 r., I CKU 108/98, niepubl. W uzasadnieniu uchwały składu 7 sędziów z dnia 14 maja 1998 r., III CZP 12/98, «OSNC» $1998 \mathrm{nr}$ 10, poz. 151 i «OSP» $1998 \mathrm{nr}$ 12, poz. 215 Sąd Najwyższy przyjąl, że „czynności podejmowane przez podmiot gospodarczy wchodzą w zakres jego działalności gospodarczej, gdy pozostają w normalnym, funkcjonalnym związku z tą dzialalnością, w szczególności podejmowane są w celu realizacji zadań związanych z przedmiotem działalności tego podmiotu". 
Cechą wyróżniającą działalność gospodarczą jest cel zarobkowy, czyli ukierunkowanie na osiągnięcie zysku ${ }^{68}$. Wprowadzone w art. 118 k.c. zróżnicowanie terminów przedawnienia „nie zależy ani od charakteru podmiotu, któremu roszczenie przysługuje, ani od charakteru rozstrzyganej sprawy (cywilna czy gospodarcza), a wyłącznie od rodzaju (kwalifikacji) roszczenia z punktu widzenia jego związku z określonym rodzajem działalności"69.

W uchwale z dnia 26 kwietnia 2002 r. ${ }^{70}$ Sąd Najwyższy przyjął, że „roszczenie spółdzielni mieszkaniowej oparte na podstawie prawnej z art. 225 k.c. w związku z art. 224 § 2 k.c. (tzw. roszczenia uzupełniające, czyli roszczenia właściciela w stosunku do samoistnego posiadacza o wynagrodzenie za korzystanie $\mathrm{z}$ rzeczy, za jej zużycie, pogorszenie lub utratę - dopisek mój - TP) jest roszczeniem związanym $\mathrm{z}$ prowadzeniem działalności gospodarczej”. Roszczenia związane z działalnością spółdzielni mieszkaniowych mają dwojaki charakter: działalność spółdzielni w ramach stosunków członkowskich nie ma charakteru gospodarczego, natomiast może mieć taki charakter w odniesieniu do innych podmiotów, „zwłaszcza w toku budowy lub administrowania cudzymi zasobami albo swobodnego gospodarowania własnymi lokalami"71. Z kolei w uchwale składu siedmiu sędziów z dnia 14 maja 1998 r. $^{72}$ oraz w uzasadnieniu wyroku z dnia 26 listopada 1998 r. $^{73}$ przyjęto, że utrzymywanie linii produkcyjnych przedsiębiorstwa $\mathrm{w}$ gotowości, ale $\mathrm{w}$ bezruchu, nie jest związane $\mathrm{z}$ prowadzeniem działalności gospodarczej.

${ }^{68}$ Por. uzasadnienie uchwały składu 7 sędziów z dnia 11 stycznia 2002 r., III CZP 63/01, «OSNC» 2002 nr 9, poz. 106 oraz «OSP» 2002 nr 10, poz. 125.

${ }^{69}$ Uzasadnienie wyroku z dnia 6 listopada 1998 r., III CKN 6/98, niepubl.

${ }^{70}$ III CZP 21/02, «OSNC» $2002 \mathrm{nr} 12$, poz. 149 oraz «PPH» 12.8 (2003), s. 54.

${ }^{71}$ Uzasadnienie postanowienia $z$ dnia 20 października 1999 r., III CKN 372/98, «OSNC» $2000 \mathrm{nr} 4$, poz. 81 oraz «OSP» $2000 \mathrm{nr} 10$, poz. 144.

72 III CZP 12/98, «OSNC» 1998 nr 10, poz. 151 oraz «OSP» $1998 \mathrm{nr} 12$, poz. 215.

${ }^{73}$ I CKU 108/98, niepubl. 


\section{Zasadnicze terminy przedawnienia}

W orzecznictwie Sądu Najwyższego przyjmuje się, że termin 10letni, zamieszczony w art. 118 k.c., stanowi zasadę, od której ustawodawca wprowadził szereg wyjątków, dwa - już w treści art. 118 k.c.: 3-letni termin przedawnienia dla roszczeń związanych z prowadzeniem działalności gospodarczej i taki sam termin - dla roszczeń o świadczenia okresowe. Zastrzeżenie, zamieszczone w tym przepisie: ,jeżeli przepis szczególny nie stanowi inaczej” odnosi się do całej treści art. 118 k.c. ${ }^{74}$

\section{Szczególne terminy przedawnienia}

W uchwale z dnia 21 października 1994 r. ${ }^{75}$ Sąd Najwyższy przyjął, że „przepisem szczególnym, o którym mowa w art. 118 k.c., jest w stosunku do roszczeń związanych z prowadzeniem działalności gospodarczej - każdy przepis ustawy przewidujący krótszy niż trzyletni termin przedawnienia". W uzasadnieniu tej uchwały podniesiono także, że niewykluczone są także dla roszczeń związanych $z$ działalnością gospodarczą terminy przedawnienia dłuższe niż trzy lata.

W uchwale z dnia 5 kwietnia $1991 \mathrm{r}^{76}$ przyjęto, że „termin przedawnienia roszczenia o zapłatę odsetek za opóźnienie w spełnieniu świadczenia pieniężnego, związanego $z$ prowadzeniem działalności gospodarczej, wynosi od czasu wejścia w życie ustawy z dnia 28 lipca 1990 r. o zmianie ustawy - Kodeks cywilny trzy lata".

${ }^{4}$ Uzasadnienia uchwał $\mathrm{z}$ dnia 21 października 1994 r., III CZP 136/94, «OSNC» 1995 nr 2, poz. 38 oraz z dnia 26 kwietnia 2002 r., III CZP 21/02, «OSNC» $2002 \mathrm{nr} 12$, poz. 149 oraz «PPH» 12.8 (2003), s. 54. Por. też uzasadnienie uchwały składu 7 sędziów z dnia 11 stycznia 2002 r., III CZP 63/01, «OSNC» 2002 nr 9, poz. 106 oraz «OSP» 2002 nr 10, poz. 125.

${ }^{75}$ III CZP 136/94, «OSNC» $1995 \mathrm{nr} 2$, poz. 38.

${ }^{76}$ III CZP 20/91, «OSNC» $1991 \mathrm{nr} 10-12$, poz. 120 oraz «OSP» $1992 \mathrm{nr} 1$, poz. 3, z glosą L. STECKIEGO, s. 6 i n. oraz R. KARCZA, «MoP» 7.3 (1999), s. 20. 
$\mathrm{Z}$ kolei w uchwale składu 7 sędziów z dnia 11 stycznia 2002 r. ${ }^{n}$ Sąd Najwyższy przyjąl, że roszczenia wynikające $z$ umowy o roboty budowlane przedawniają się $w$ terminach określonych $w$ art. 118 k.c. $^{78}$

\section{Zróżnicowanie zasadniczych terminów przedawnienia}

Wprowadzenie krótkiego, 3-letniego terminu przedawnienia roszczeń związanych z prowadzeniem działalności gospodarczej, w zestawieniu $\mathrm{z}$ zasadniczym terminem 10-letnim jest $\mathrm{w}$ orzecznictwie Sądu Najwyższego uzasadniane specyfiką tej działalności, tj. jej zawodowym charakterem oraz wymaganiami obrotu gospodarczego. W ocenie Sądu Najwyższego roszczenia takie, ze względu na dynamikę i pewność obrotu, muszą przedawniać się stosunkowo szybko ${ }^{79}$. Zróżnicowanie w długości terminów przedawnienia uzasadnia się także potrzebą wzmożonej ochrony konsumenta ${ }^{80}$.

${ }^{n}$ III CZP 63/01, «OSNC» 2002 nr 9, poz. 106 oraz «OSP» 2002 nr 10, poz. 125.

${ }^{78}$ Wątpliwość, przedstawiona Sądowi Najwyższemu do rozstrzygnięcia, pojawiła się w związku z nowym ukształtowaniem umowy o roboty budowlane, która - przed 1 października 1990 r. - mogła być zawierana jedynie pomiędzy jednostkami gospodarki uspolecznionej. Uzasadnieniem poglądu zaprezentowanego przez powiększony skład Sądu Najwyższego było przyjęcie, że art. $656 \S 1$ k.c. - zawierający odesłanie do umowy o dzieło - nie odsyła do art. 646 k.c., przepisu regulującego przedawnienie roszczeń w umowie o dzieło. Nadto podkreśla się, że nie ma przeszkód, by roszczenia wynikające $z$ niewykonania lub nienależytego wykonania tej samej umowy przedawniały się w różnym terminie, „w zależności od charakteru roszczenia, zdeterminowanego statusem podmiotu, któremu roszczenie przysługuje”. Obrony takiego stanowiska upatruje się w treści art. 118 k.c. Sąd Najwyższy zauważył, że „podmiot, który zajmuje się w sposób ciągły, zorganizowany i zarobkowy oddawaniem obiektów budowlanych, jest przedsiębiorcą bez względu na status cywilnoprawny, a więc profesjonalistą, od którego można i należy wymagać szybkiego formulowania i dochodzenia własnych roszczeń wobec swego kontrahenta".

79 Tak w uzasadnieniu uchwały składu 7 sędziów $z$ dnia 11 stycznia 2002 r., III CZP 63/01, «OSNC» 2002 nr 9, poz. $106 \mathrm{i}$ «OSP» $2002 \mathrm{nr} 10$, poz. 125 oraz uchwały z dnia 21 października 1994 r., III CZP 136/94, «OSNC» 1995 nr 2, poz. 38.

so Tak w uzasadnieniu uchwały składu 7 sędziów z dnia 11 stycznia 2002 r., III CZP 63/01, «OSNC» 2002 nr 9, poz. 106 oraz «OSP» 2002 nr 10, poz. 125. 


\section{PRZEPISY INTERTEMPORALNE}

Każdej niemal zmianie reguł postępowania towarzyszy konieczność rozstrzygnięcia kolizji pomiędzy przepisami dawnymi a prawem nowym. Zasada ta jest szczególnie aktualna w dziedzinie przedawnienia roszczeń, immanentnie związanej z upływem czasu. Kolizja norm w stosunkach dotyczących przedawnienia może mieć miejsce jedynie wówczas, gdy termin przedawnienia zaczyna biec pod rządami „starych" przepisów, a przed jego upływem zaczynają obowiązywać nowe zasady. W związku z tym do roszczeń, które uległy przedawnieniu przed 1 października 1990 r., stosuje się przepisy dotychczasowe. W konsekwencji upływ tych terminów sąd uwzględnia $z$ urzędu ${ }^{81}$.

Zgodnie $\mathrm{z}$ treścią art. 8 ustawy z dnia 28 lipca 1990 r. o zmianie ustawy - Kodeks cywilny ${ }^{82}$, do powstałych przed dniem jej wejścia w życie, a jeszcze nie przedawnionych roszczeń, które ze względu na strony stosunków, z jakich te roszczenia wynikły, przedawniały się według przepisów dotychczasowych $\mathrm{z}$ upływem jednego roku, stosuje się przepis art. 118 k.c. o przedawnieniu trzyletnim. Przy czym bieg tego terminu liczy się od dnia wymagalności roszczenia. Przepis ten stał się źródłem wątpliwości interpretacyjnych zamykających się $w$ pytaniu, czy dotyczy on jedynie terminów ogólnych $z$ art. 118 k.c., czy ma też zastosowanie w sytuacjach, gdy przepis szczególny przewiduje dla określonego stosunku termin krótszy od trzyletniego. W uchwale z dnia 5 października 1993 r. $^{83}$ Sąd Najwyższy przyjąt, że „roszczenia, o których mowa w art. 8 ustawy $z$ dnia 28 lipca 1990 r. o zmianie ustawy - Kodeks cywilny, przedawniają się $z$ upływem terminu określonego $\mathrm{w}$ tym przepisie, choćby wynikały $\mathrm{z}$ tytułu sprzedaży dokonanej w ramach działalności przedsiębiorstwa sprzedawcy." W ocenie Sądu Najwyższego, wyrażonej w uzasadnieniu uchwały,

${ }^{81}$ Tak w uzasadnieniu wyroku z dnia 21 marca 1997 r., III CKN 25/97, niepubl.

${ }^{82}$ Przywolanej w przyp. 1.

${ }^{83}$ III CZP 135/93, «OSNCAPiUS» 1994 nr 5, poz. 100. 
nie ma żadnych podstaw, by odstąpić od jednoznacznego unormowania zawartego w przywołanym przepisie i uznać, że odnosi się ono jedynie do „ogólnych” terminów przedawnienia, określonych w art. 118 k.c., a nie dotyczy terminów zawartych w przepisach szczególnych.

W uzasadnieniu wyroku z dnia 24 kwietnia 2002 r. ${ }^{84}$ Sąd Najwyższy przyjąıł, że jeżeli w ustawie zmieniającej brak jest reguł intertemporalnych, to w zakresie nieuregulowanym należy stosować przepisy ustawy z dnia 23 kwietnia 1964 r. - przepisy wprowadzające Kodeks cywilny ${ }^{85}$. Podobne stanowisko Sąd Najwyższy zają W uchwale $z$ dnia 28 lutego $1994 r{ }^{86}$ przyjmując, że do przedawnienia roszczenia, które było objęte dyspozycją art. $229 \S 2$ k.c., skreślonego przez ustawę z dnia 28 lipca 1990 r. ${ }^{87}$, może mieć zastosowanie w drodze analogii art. XXXV przepisów wprowadzających Kodeks cywilny ${ }^{88}$. W ocenie Sądu Najwyższego art. 8 ustawy zmieniającej Kodeks cywilny nie obejmuje sytuacji, jaka powstała po skreśleniu art. $229 \S 2$ k.c. Unormowania tej ustawy dotyczące materii intertemporalnych $\mathrm{w}$ zakresie przedawnienia nie są wyczerpujące. W związku z tym należy sięgać „do pewnych prawideł wynikających z polskiego prawa międzyczasowego, tak aby nie podważać w społeczeństwie zaufania do obowiązującego ustawodawstwa i aby każdy mógł ze spokojem według tego ustawodawstwa swe sprawy prowadzić bez obawy, iż wprowadzone zmiany, w tym przypadku polegające na skróceniu terminu przedawnienia, jego plany pokrzyżują i udaremnią zamierzone dochodzenie roszczeń".

W uzasadnieniu wyroku z dnia 15 maja 1998 r. ${ }^{89}$ Sąd Najwyższy przyjął, że „art. $263 \S 2$ k.c., przewidujący szczególny termin

${ }^{84}$ V CKN 1004/00, niepubl.

${ }^{85}$ Dz.U. Nr 16, poz. 94, ze zm.

${ }^{86}$ III CZP 9/94, «OSP» 1995 nr 1, poz. 3, z glosą aprobującą J. IGNATOWICZA, s. 9-10.

${ }^{87}$ Przywolaną w przyp. 1.

${ }^{88}$ Przywolanych w przyp. 86.

${ }^{89}$ III CKN 485/97, «OSNC» 1999 nr 1, poz. 10. 
przedawnienia określonych w nim roszczeń przysługujących jednostce gospodarki uspołecznionej, choć uchylony dopiero dnia 28 grudnia 1996 r., stał się z dniem 1 października 1990 r., po wyeliminowaniu z kodeksu cywilnego zróżnicowania osób prawnych na jednostki gospodarki uspołecznionej i jednostki organizacyjne nie będące jednostkami gospodarki uspolecznionej, przepisem bezprzedmiotowym. 